\title{
HISTORY WILL TEACH US NOTHING? THE EVOLUTION OF THE COPYRIGHT FRAMEWORK FOR EDUCATIONAL USES
}

What does it mean to learn and to be educated in the twenty-first century? This question underlies an essay on how the Internet shapes education, and how education shapes the Internet. ${ }^{1}$ The part of this question that addresses the tools, methods and activities used in the process of teaching and learning necessarily touches upon the legal framework, particularly copyright. The scope of the applicable exceptions and limitations facilitating education has been debated extensively at an international intellectual property forum ${ }^{2}$ that considered development policies, and also within the European Union's goal of knowledge economy. ${ }^{3}$ The discussion led to legislative proposals which were finalized in the EU in 2019. This article seeks to join this discussion with the particular objective of performing a critical analysis of the concept of 'illustration for teaching' which underlies both international and European Union law, and is thus accepted in many countries.

A very good example to illustrate this problem is the CJEU judgment in Renckhoff, also called the Cordóba case. ${ }^{4}$ The photo of Cordóba city, authored by the professional photographer Dirk Renckhoff, was used in a presentation made by a German pupil for a Spanish class. The presentation was subsequently uploaded to the school's website, with a reference to the website as the source of the photo. According to the facts of the case, neither the source nor the pupil cited the author's name. The photographer claimed infringement of the reproduction right and the right of communication to the public. The lower instance court upheld his claims, and the BGH (Bundesgerichtshof) referred a question for a preliminary ruling, on the scope of the right of communication to the public. Both the CJEU and BGH subsequently agreed that the act of posting a photo online constituted public communication of a photo. ${ }^{5}$ Interestingly from the perspective of this article, AG Sánchez-Bordona invoked Article 5(3) a) of the InfoSoc Directive, ${ }^{6}$ to argue that the exception for 'illus-

${ }^{1}$ Selwyn (2014).

2 Torres, Xalabarder (2019).

${ }^{3} \mathrm{COM}(2008) 466$ final.

${ }^{4}$ The judgement of the Court of 7.08.2018 in case C-161/17 Land Nordhrein Westfalen v Dirk Renckhoff, ECLI:EU:C:2018:634.

${ }^{5}$ Urteil des Zivilsenats vom 10.01.2019, I ZR 267/15 <http://juris.bundesgerichtshof.de/cgibin/rechtsprechung/document.py?Gericht=bgh\&Art=en\&az=I\%20ZR\%20267/15\&nr=96761>.

${ }^{6}$ Directive of the European Parliament and the Council of 22 May 2001, on the harmonisation of certain aspects of copyright and related rights in the information society, OJ L 167, 22.6.2001: 10-19. 
tration for teaching' would apply in this case, and cover the pupil's activity. To reinforce this argument, AG Sánchez-Bordona, stated that this exception 'cannot be reduced to a minimum, which is what would happen if it were limited to allow teachers to illustrate the content of their courses or lessons' ${ }^{7}$ The BGH however, found that it was doubtful whether this use was indeed an 'illustration for teaching', and as the access to the presentation was open (not on an intranet, nor any school's platform) it was outside the scope of permissible quotation or educational use. ${ }^{8}$ In his opening sentences, AG Sánchez-Bordona, pointed briefly to the changes in education, from analogue to digital uses and to the undoubtful educational context of this activity. ${ }^{9}$ The European Copyright Society approved AG's approach and expressed concerns that such student activity would constitute copyright infringement. ${ }^{10}$ On the other hand, ALAI is of the opinion that such a practice 'doubtless exceeds the scope of a broadcast by way of illustration for teaching'. ${ }^{11}$ The CJEU was silent on the interpretation of Article 5(3) a), as it was not part of the referral by the national court, and pointed only to the need to maintain the balance between the right to education and protection of intellectual property rights. ${ }^{12}$ What exactly constitutes a balanced approach in this case is subject to the diverse opinions of scholars. This article argues that the concept of illustration for teaching' supports the 'overly restrictive and rigid approach to copyright interpretation', observed by the European Copyright Society as a general tendency undermining the respect and social support of copyright rules. ${ }^{13}$ Therefore, a new approach to reconcile the objectives of education and copyright is proposed.

\section{THE USE OF WORKS AS AN 'ILLUSTRATION FOR TEACHING' IN INTERNATIONAL AND EUROPEAN UNION LAW}

\section{The origins of the concept of 'illustration for teaching'}

The basic international framework for limitations and exceptions answering educational needs is provided in the Berne Convention. ${ }^{14}$ The original provisions of the 1886 text did not use the phrase 'illustration' for teaching, but rather 'teaching purpose': '[...] the right to include excerpts from literary or artistic works for use in publications for teaching or scientific purposes.' It

7 The opinion of Advocate General Campos Sánchez-Bordona in case C-167/15, of 25.04.2018: para. 114.

8 See Ling (2019).

9 Opinion para. 123.

10 European Copyright Society (2018): 2.

11 Association Littéraire et Artistique Internationale (2018): 3.

12 C-161/17, para, 43.

13 European Copyright Society (2018): 3-4.

14 For the related or neighbouring rights, the Rome Convention of 1961 in Article15(1) (d) allows parties to the Convention to introduce or maintain, among others, an exception or limitation for 'use solely for the purposes of teaching or scientific research.' 
was left to the countries of the Union to provide (or not) for detailed solutions in the national law. ${ }^{15}$ The change from 'publications for teaching' to 'illustration in publications, broadcasts or sound or visual recordings for teaching' took place decades later, in the 1967 Stockholm Act. It was still to be a matter of the countries of the Union, and for the special agreements to permit the utilization, to the extent justified by the purpose, of literary or artistic works by way of illustration in publications, broadcasts or sound or visual recordings for teaching, provided such utilization is compatible with fair practice'. ${ }^{16}$

In Article 8 of 1886 text, approach similar to that applied to use of quotations is clearly visible: excerpts from works can be used in a normative framework encompassing certain purposes. ${ }^{17}$ The Stockholm Act introduced a concept that is considered broader: not only 'excerpts', but even whole works, and not only text publications, but also other multimedia materials of the time. ${ }^{18}$ This close link between quoting and illustration ${ }^{19}$ should not be disregarded as a source of further uncertainties with regard to the scope of the permitted use of illustration for teaching. It is pointed out that Article 10(2) allows for a larger scope of exempted uses than Article 10(1), and is characterized as 'open, flexible and technology neutral'. ${ }^{20}$ This provision sets 'the outer limits' for national legislation, ${ }^{21}$ and four concepts are key: utilization, teaching, and the justification by purpose and fair practice, which all emphasize the functional aspects of the use at stake.

To summarize the comments, Daniel Seng seems to accept that 'by way of illustration' serves as the limitation of the scope of use of the work. ${ }^{22}$ Claude Masouyé focuses on explaining 'teaching', as including teaching at all levels: in educational institutions, municipal and state schools, and private schools. ${ }^{23}$ Sam Ricketson also seems to focus on 'teaching' but notes, that the concept of illustration imposes 'some limits'. ${ }^{24}$ Raquel Xalabarder finds that the crucial feature of this exception is: 'by way of illustration [...] for teaching', and argues it is not narrower than 'educational purpose', as it was introduced to

${ }^{15}$ Comparative document, prepared for the centenary of the Berne Convention, 1986. <ftp:// ftp.wipo.int/pub/library/ebooks/wipopublications/wipo_pub_877e.pdf>. Act of 1886 Article 8.

16 Stockholm Act of the Berne Convention of 1967, Article 10 retained in the Paris Act of 1971.

17 Masouyé (1978): 58.

18 Ricketson (2003): 14; Dussolier (2013): 357 and the literature cited therein. Ricketson (2003) points out that the distribution of a work as a part of an original programme or a broadcast distributed by cable should be understood as expressly excluded from the scope of Article 10(2): 15. Seng (2016) finds that Article10(2) sanctions the creation of limitations and exceptions that go beyond 'reproduction' and 'communication': 12. Xalabarder (2009) sees no reason to leave digital means and online teaching out of the scope of Article 10(2): 14.

19 As Masouyé (1978: 60), notes that Article 10(2) lays down the same conditions as Article 10(1) for quotations.

20 Xalabarder (2009): 17.

21 Ricketson (2003): 14.

22 Ricketson (2003): 12.

${ }^{23}$ Masouyé (1978): 60; notes, that the understanding of 'teaching' was agreed on during the Stockholm revision.

${ }^{24}$ Ricketson (2003): 14. 
respond to concerns about the amount of works used. ${ }^{25}$ Article 10(2) of the Berne Convention thus contains two major limitations: 'the extent justified by purpose' and '[compatibility] with fair practice'. ${ }^{26}$

While Article 10(2) of the Berne Convention was found to be flexible and technologically neutral, in contrast Article 5(3) a) of the InfoSoc Directive, allowing for the 'use for the sole purpose of illustration for teaching or scientific research', was found to be worded in open-ended manner, as it does not limit the beneficiaries or the protected subject matter concerned. It is pointed that the key factor circumscribing the exception is its purpose: illustration for teaching. ${ }^{27}$ In the context of EU law, some authors also focus on 'teaching purpose' and the extent of the work used, rather than on the concept of illustration as such..$^{28}$ Silke von Lewinski refers to the concept of 'illustration' to narrow the uses permitted under the exceptions. As 'teaching' is not defined, it is proposed that it should be understood in line with the interpretation of the Berne Convention: limited to educational institution. Teaching is furthermore understood as the conveyance of knowledge and experience to others. This interpretation excludes, for example, the use of works for examinations. ${ }^{29}$ Séverine Dussolier criticizes this approach as theoretical and too restrictive. As the concept of illustration originated in the Berne Convention, it should be borne in mind that it was not aimed at limiting the scope of the exceptions for teaching that existed until 1967. Its meaning is confined to the discussion on the length of work that could be used for teaching purposes ${ }^{30} \mathrm{It}$ is thus evident how Article 5(3) a) is open to different interpretations of its scope, even if it is always placed in the context of the Berne Convention. The uncertainties concern the beneficiaries, including whether both teachers and pupils/ students may use a work by way of illustration for teaching, and whether the concept of 'illustration for teaching' is narrower than educational/ teaching purpose.

\section{2. 'Illustration for teaching' in the recent initiatives on educational uses}

For more than a decade, both at the EU level and under the auspices of the World Intellectual Property Organization (WIPO), limitations and exceptions, particularly those supporting research and education, were subject to closer scrutiny. ${ }^{31}$ The major objectives have been: better harmonization, as studies showed a mosaic of national solutions; and adjusting exceptions and limitations to the needs of modern education. At the international level, exceptions or limitations concerning use for illustration for teaching were not mandatory, and the same was true in the European Union until 2019. The InfoSoc Directive provided for a 'ceiling', leaving it to the Member States to decide whether

\footnotetext{
25 Xalabarder (2009): 15.

26 Xalabarder (2009): 16.

27 Dussolier (2013): 359.

${ }_{28}$ Dreier (2006): 45.

29 von Lewinski (2010): 1043.

30 Dussolier (2013): 362. See also Xalabarder (2009): 17.

31 E.g. European Commission (2016); Nobre (2017).
} 
or not to introduce any permitted use for teaching purposes. If they did, however, Article 5 of the InfoSoc Directive provided for the framework that Member States could not exceed. ${ }^{32}$

In 2018, a Treaty on Copyright Exceptions and Limitations for Educational and Research Activities (TERA), prepared by civil society organizations, was presented. ${ }^{33}$ This proposal of a special agreement in the meaning of the Berne Convention, draws upon studies and proposals submitted to WIPO. Its major achievement would be obliging Member States to implement: 'all appropriate measures to respect, protect and fulfill the right to receive education and conduct research through appropriate exceptions and limitations' (Article 3). The proposal includes detailed permitted uses for teaching, learning and the preparation of educational materials (Article 5), and goes beyond the concept of 'illustration'. ${ }^{34}$

However, the concept of 'the sole purpose of illustration for teaching' remained prominent in the new Digital Single Market (DSM) Directive. ${ }^{35}$ Article 5 of the DSM Directive provides for the mandatory introduction of an exception or limitation to allow the digital use ${ }^{36}$ of works and other subject-matter for the sole purpose of illustration for teaching to the extent justified by the non-commercial purpose to be achieved. It establishes two conditions: (1) the use takes place under the responsibility of an educational establishment, on its premises or at other venues, or through a secure electronic environment accessible only to the establishment's students/ pupils or teaching staff; (2) the source including the author's name is indicated, unless impossible. With this provision, the EU aimed at facilitating and fostering e-learning, including the cross-border dimension, and the use of digital materials in educational activities. ${ }^{37}$ In the light of the preamble: 'Illustration' refers to the length, the amount of a work (or a subject matter) used, together with an interpretation favourable to encompass not only 'conveying knowledge' but also learning, complementing teaching or enriching the subject matter taught. ${ }^{38}$

${ }^{32}$ No permitted use for software is provided for in Directive 2009/24/EC of the European Parliament and of the Council of 23 April 2009 on the legal protection of computer programs, OJ L 111, 5.5.2009: 16-22; and separate provisions concern databases Directive 96/9/EC of the European Parliament and of the Council of 11 March 1996 on the legal protection of databases OJ L 77, 27.3.1996: 20-28, and related rights in the Article 10(1) d) of the Directive 2006/115/EC of the European Parliament and of the Council of 12 December 2006 on rental rights and lending rights and on certain rights related to copyright in the field of intellectual property (codified version), OJ L 376, 27.12.2006.

${ }_{33}<\mathrm{http}: / /$ infojustice.org/tera>

${ }^{34}$ Art. 5 (2) a) ii): performing or communicating works by way of illustrations or for comment, criticism, or review [...] (as part of teaching activities); Article5 (2) c) i): 'using works by way of illustration or for comment, criticism, or review in publications, broadcasts, audiovisual works, or sound recordings' in the course of preparing of teaching materials.

${ }^{35}$ Directive (EU) 2019/790 of the European Parliament and of the Council of 17 April 2019 on copyright and related rights in the Digital Single Market and amending Directives 96/9/EC and 2001/29/EC, OJ L 130, 17.5.2019: 92-125.

${ }^{36}$ An exception or limitation to the rights provided for in Article 5(a), (b), (d) and (e) and Article 7(1) of Directive 96/9/EC, Articles 2 and 3 of Directive 2001/29/EC, Article 4(1) of Directive 2009/24/EC and Article 15(1) of this Directive (new exclusive right in the press publications).

${ }^{37}$ Rec. 19 of the Directive (EU) 2019/790.

${ }^{38}$ Rec. 21 The exception or limitation provided for in this Directive for the sole purpose of illustration for teaching should be understood as covering digital uses of works or other subject 
Conclusions drawn from international and EU law support the view that the concept of illustration for teaching is not necessary for the sake of clarification of the relevant provisions, or maintaining balance between rightholders and users. This concept was never found to be particularly detrimental as a source of uncertainties. However, it is often perceived as limiting the scope of the educational use in question. On the other hand, it is sometimes explained as supporting the use of whole works in the process of teaching. Most liberal interpretations consider 'illustration' as applicable only to a choice of a particular work, the necessary link between the subject matter taught and the work used. From the national perspective, this ambiguity in interpretation adds to the choices that have to be made: whether and how to implement any exception or limitation for teaching. It is noted that not all the countries-parties to the Berne Convention apply the concept of 'illustration for teaching', nor do all European Union countries. ${ }^{39}$ In some countries, such as France, the definition of an 'illustration for teaching' may be offered as 'the use of work, or an extract, only to clarify or support a discussion, development or argument forming the main subject of teachers, teaching works of pupils and students and research works. ${ }^{30}$ The UK Intellectual Property Office explains that the purposes of copying for 'illustration' encompasses minor uses, 'such as displaying a few lines of poetry on interactive whiteboard. ${ }^{41}$ Poland was an example of a country that applied the broad term 'use' and did not use the phrase 'illustration for teaching'. This seem to have resulted in the flexibility noted in a study on modern educational practices. ${ }^{42}$ This aspect of Polish legislation has substantially evolved, however.

\section{THE POLISH LEGAL FRAMEWORK FOR THE USE OF WORKS BY EDUCATIONAL INSTITUTIONS}

\section{The evolution of provisions on permitted use for teaching}

When the first Polish copyright act was drafted in the 1920s, Poland was bound by the Berlin text of the Berne convention. ${ }^{43}$ The objective at the time was to have a unified law for a reborn country, having had different laws im-

\footnotetext{
matter to support, enrich or complement the teaching, including learning activities. The distribution of software allowed under that exception or limitation should be limited to the digital transmission of software. In most cases, the concept of illustration would, therefore, imply the use only of parts or extracts of works, which should not substitute for the purchase of materials primarily intended for the educational market.

${ }^{39}$ Seng (2016): 50; Dussolier (2013): 368, 374.

${ }^{40}$ Dussolier (2013: 369) points to Protocol d'accord transition.

${ }^{41}<$ https://www.gov.uk/guidance/exceptions-to-copyright\#teaching>

${ }^{42}$ See tables on the application of the laws of the different countries, Nobre (2017): 26-30.

${ }^{43}$ The first Polish Copyright Law Act dates back to 1926 (Journal of Laws [JL] 1926, No. 48 item 286), and revised and codified in 1935 (Obwieszczenie Ministra Sprawiedliwości z dnia 25 kwietnia 1935 r. w sprawie ogłoszenia jednolitego tekstu ustawy z dnia 29 marca 1926 r. o prawie autorskiem). Poland acceded to the Berne Convention 28.01.1920, ratified in 1934, adhered to the Paris Act of the Berne Convention in 1990.
} 
posed by the occupants of different parts of Poland: Germany, Russia and Austria. ${ }^{44}$ The research shows that at least some of those laws included provisions on teaching purposes. ${ }^{45}$ There were many educational challenges after the First World War, including the organization of a whole education system with different ethnic and religious groups and different classes in the society. The need to educate society, as the foundation for the strong country that Poland had hoped for years to be, is visible in the preparatory works for the new copyright law, work on which started promptly and resulted in the 1926 Copyright Act. The major issue at the time was how copyright protection should be structured, with reference to property law and questions about civil or criminal liability. The limits of copyright were discussed mostly in terms of protection, but the existence of public interest was also recognized. ${ }^{46} \mathrm{~A}$ section on permitted use was included at the beginning in the Copyright Act. It was challenged by the organizations of authors during the revision process in 1935, yet the amendments sustained or even emphasized the need to establish a balance between the author's rights and societal needs. ${ }^{47}$ While on the one hand this section was described as incompatible with the principle of the full protection of authors, on the other it was praised as incorporating the whole social and cultural value of this Act. ${ }^{48}$ Stefan Ritterman, in the first commentary to the 1926 Act, emphasized one ratio legis for provisions on quotations and educational use of different types of works pertaining to the literary, musical and visual arts: the democratization of knowledge and the resulting progress. ${ }^{49}$ To summarize briefly, in the 1920s and 1930s Polish copyright law permitted the following uses: quoting literary works in other works for explanation or teaching (Article 13(3)), quoting musical works in teaching materials, using musical works in the course of the lecture for explanatory purposes (Article 14(2)), as well as reproducing visual art works in teaching materials and using them to explain and teach (Article 15(2)).

After the war, in the period of the Polish People's Republic (PRL), a new copyright act was enacted in $1952 .{ }^{50}$ In the provisions on permitted use for educational needs, this act followed the same pattern as the previous statutes, namely distinct provisions dedicated to different works, allowing: the quotation of literary works for explanatory or teaching purposes; lecturing on or reciting the work for free, if it was published; quoting musical works in teaching materials; performing works for teaching purpose free of charge; and reproducing and using visual art reproductions in teaching. At the same time, social needs were underlined, and it was noted that in general capitalist countries put more emphasis on authors' right when drafting provisions on per-

${ }^{44}$ Groeger (1937): 19.

${ }^{45}$ Marcinkowska (2004): 65.

${ }^{46}$ Protokoły z obrad Komisji Kodyfikacyjnej [Minutes of the Codification Committee] 1921: $7-11,16$.

${ }^{47}$ Groeger (1937): 47-48.

${ }^{48}$ Groeger (1937): 137-138.

${ }^{49}$ Ritterman (1937): 101 and 102.

${ }^{50}$ The Copyright Act (Ustawa o prawie autorskim) of 10 July 1952, JL 1952, No. 34, item 234. 
mitted use. ${ }^{51}$ Social needs were underscored as an explanation for drafting the scope of permitted use broadly, when it comes to institutions, which function as intermediaries in access to culture and education. ${ }^{52}$ However, these provisions were criticized for the incoherence resulting from the different scope of permitted use with respect to different types of work..$^{53}$ It is noted that the 1952 Act did not allow for flexibility in its application, that is, neither allowing a synthetic approach nor adjusting the law to the changes in society and the conditions for the flow of information..$^{54}$

The major shift in addressing permitted use for educational needs took place in the current act of $1994 . .^{55}$ The new act was drafted in the context of economic and social changes in Poland after 1989, the association with the European Economic Community, ${ }^{56}$ and the re-organization of education in Poland. ${ }^{57}$ It should be noted, that at until 2018 Poland was a developing country, with particular needs to boost the economy, innovation and education..$^{58}$

The synthetic approach to the concept of a work in the Copyright Act of 1994 (Article 1) was coupled with the synthetic approach to permitted use that in principle did not differentiate between categories or works pertaining to the literary, musical or visual arts. Article 27 of the Copyright Act, key from the perspective of educational needs, originally provided that: research and educational institutions shall be allowed, for the purpose of teaching or in order to conduct their own research, to use published works in their original version and in translation, and to make copies of excerpts of works. This provision raised two important questions: firstly on the scope of benefiting institutions, and secondly on the scope of 'use' without the author's authorization. After three revisions to clarify certain issues and to adjust the provision to Article 5(3) a) of the InfoSoc Directive, this provision now allows the use of works already communicated to the public (both their original version and translations) for the purpose of illustration in teaching and research activities, and to make copies of 'small' works, as well as parts of other works, also on the condition that works were communicated to the public. In 2015, Article 27(2) introduced the express possibility to make works available on demand, to the closed circle of recipients who are teaching, learning or conducting research, and who are identified by the beneficiaries of Article 27.59

Polish copyright struggled for long to define 'research and educational institutions'. Before 2015 the statute did not contain any express limits on how

51 Grzybowski et al. (1973): 159.

52 Preussner-Zamorska et al. (2017): 577.

53 Preussner-Zamorska et al. (2017): 577; Błeszyński (1985): 134.

54 Preussner-Zamorska et al. (2017): 577.

55 The Act of 4 February 1994 on Copyright and Related Rights (Ustawa o prawie autorskim i prawach pokrewnych), consolidated text, JL 2019, item 1231 as amended.

56 Marcinkowska (2004): 72.

57 Levitas, Herczyński: 3-15.

$58<$ https://content.ftserussell.com/sites/default/files/research/poland---the-journey-to-developed-market-status_final.pdf>

59 Article 100 of the Copyright Act provides that permitted use provisions apply in principle to all related rights regulated in the Act. 
educational institutions should be understood. It was thus proposed to include all schools, public and private, also language schools or ballet schools, but not those entities that offered courses or trainings as a marginal activity. ${ }^{60}$ The limits of what a school is, and what only has 'school' in its name, like a yoga school or commercial dance 'school' offering courses or activities for children, led to further clarifying proposals, namely that there should be link between the school in question and the national system of education, ${ }^{61}$ which allows for the provision of quite a detailed list of educational institutions. ${ }^{62}$ The revisions of 2015 and 2018 led to the introduction of a legal definition of an educational institution, in Article 6(1) 13 of the Copyright Act, and including higher education institutions according to the statutes regulating the educational system and higher education in Poland. ${ }^{63}$ This enumerative approach clearly results in restricting entities allowed to make educational uses without the authors' consent, ${ }^{64}$ excluding language schools, for example. Some authors indicate that it encompasses institutions that play a particularly important role in education, ${ }^{65}$ but a critical approach denying justification for the resulting restrictions is also present. ${ }^{66}$

\section{2. 'Illustration for teaching' in Polish law}

Until 2015, the Copyright Act did not expressly mention 'illustration for teaching', but rather a teaching purpose such as listening to or performing a work. ${ }^{67}$ The teaching purpose was also linked to the content of the program for teaching as a basis for school education. It was considered that this could include both the activities of teachers and pupils, during classes (by showing or performing a work), and in preparation for exams and homework. ${ }^{68}$ The link to the mandatory program for teaching echoes the explanations provided for in the former Article 29(2) (now after amendments Article 27') on the preparation of anthologies as teaching materials. ${ }^{69}$ In this approach, the link to the

60 Traple (2011): 264.

61 Osmańska (2014): 204-206.

62 Stanisławska-Kloc (2015): 414-415.

${ }^{63}$ Article 6(1) 13 of the Copyright Act refers to Article 2 of the Education Law of 2016 (JL 2018, item 966 as amended) but also names other institutions like schools under Polish consulates, or some military schools. Article 27(1) refers furthermore to the Law on Higher Education of 2018 .

64 Gienas (2016); Błońska (2019): 594.

65 Preussner-Zamorska et al. (2017): 637.

66 Błońska (2019): 594.

67 Traple (2011): 265.

68 Stanisławska-Kloc (2015) was in favour of including e-learning as one of the activities covered by Article 27, but together with restrictive understanding of 'teaching purpose' and application of the concept of 'illustration', within limits like those applicable to quotations, for example not to replace teachers' own input. This reasoning leaves certain doubts whether the 'teaching purpose' should be equated with the 'illustration for teaching' concept. However, it may be subject to revision, as the amendments in 2015 result in the express inclusion of e-learning activities in Article 27(2): 416.

69 Bukowski, Marcinkowska (1997): 95. 
teaching program justifies the choice of a particular work and its use in an educational purpose. In this context it seems unclear, whether the concept of 'teaching purpose' was to be understood uniformly for teaching in the premises of educational institutions and in e-learning.

The introduction of the concept of 'illustration for teaching' as part of the amendments of 2015, is perceived as substantially narrowing the permitted use to only those uses that offer the possibility to access a work or to offer insight into the work's content. ${ }^{70}$ This opinion refers to the explanatory memorandum, annexed to the proposal, which states that illustration in the course of teaching means an activity of explaining, deepening and illustrating the subject matter taught, to facilitate and complement the conveyance of knowledge. ${ }^{71}$ Examples include: the presentation of research results, lectures, and multimedia presentations. ${ }^{72}$ This concept of 'illustration' reflects the active teacher-passive students approach, and some of the commentators do indeed focus on the concept of the transfer of theoretical and practical knowledge as the core of educational activities. ${ }^{73}$ However, the interpretation going beyond the literal meaning of 'illustration' is also offered The new reading seems to treat 'illustration' as relating to the subject matter taught, allowing for any use and not simply offering access or showing a work. It is argued that we can accept a more liberal approach than in the previous statutes. ${ }^{74}$ As a result, however, 'illustration' becomes equivalent to with the teaching purpose. ${ }^{75}$

Summing up the scope of the permitted use for educational institutions in Poland, two interpretative possibilities can be outlined. One reflects strict interpretation and limits the scope of activities concerned to the predominantly passive transfer of knowledge, through lectures and presentations. The other results in marginalizing the concept of illustration as descriptive and relative, and covers a broad range of activities, including pupils/ students participation. It seems that the latter line of interpretation is based on the assumed compliance of Polish law with the Berne Convention (Article10 (2)) and InfoSoc Directive. ${ }^{76}$ The reasoning here might be as follows: since Polish law was viewed as not exceeding the framework established by the Berne Convention, when the concept of "illustration" was not used, ${ }^{77}$ then its use or absence changes practically nothing in the interpretation of the scope of the activities

70 Barta, Markiewicz (2016): 257.

${ }^{71}$ Druk sejmowy nr 3449 - uzasadnienie: 15; this concept is followed by some commentators, see Pacek (2019): point 3.

${ }^{72}$ Druk sejmowy nr 3449 - uzasadnienie: 15.

73 Gienas (2016): 286.

74 Błońska (2019): 600.

75 Błońska (2019) herself notes the difference between the concept of 'illustration' in the Act of 1926, and the concept of 'teaching purpose' in the Act of 1952 with respect to the visual arts: 592 .

76 The explanatory memorandum accompanying the 2015 amendments points to the general need to ensure further compliance with EU law, but it is not explained whether the lack of the concept of 'illustration' was important in this context: 1 and 15; Osmańska (2014) suggests that the amendment reflects better the provisions of InfoSoC Directive: 207.

77 Traple (2011): 265. 
concerned. For example, many authors before and after the introduction of the 'illustration for teaching' proposed including the student/ pupil's actions in the learning process as covered by Article 27. ${ }^{78}$

\section{CONCLUSIONS: ACTIVE PUPILS, ACTIVE STUDENTS AND THE NEEDS OF MODERN EDUCATION}

Based on the analysis in the previous sections, I argue that the concept of 'illustration for teaching' is redundant, and leads to a false perspective on the needs of modern education. It has its origins in the form that education took a hundred years ago and in the practices of quoting and preparing of teaching materials. In many modern studies the attention shifted to what is now described in EU law as 'digital uses' or 'digitally supported educational activities'. However, the focus on the use of digitalized protected subject matter, or on distance learning, cannot be squared with the needs of modern education. ${ }^{79}$ I view the formulation 'illustration for teaching' as reflecting a passive approach to education, centred on the teacher conveying knowledge, by activities such as lecturing, demonstrating, displaying, playing some videos or showing artworks.

The first major problem with this approach is whether and how it encompasses students/ pupils' activities. Some authors suggest that Article 5(3) a) InfoSoc Directive or Article 27 of the Polish Copyright Act needs to include activities undertaken by students/ pupils, as inherent to the concept of teaching. ${ }^{80}$ EU law seeks to clarify that aspect in the recent DSM Directive, where learning is expressly mentioned in the preamble. Seng, in his study on international and national laws, points to the important nexus of private use provisions and 'educational instruction'. ${ }^{81}$ The primary assumption is that what students/ pupils do is to a great extent considered private or personal use. The distinction between private and public use in educational institutions is blurred. ${ }^{82}$ The interpretation that might follow is that also students/ pupils may illustrate their presentations, talks and assignments with others works. However, 'learning', insofar as it is the activities of students/ pupils, demands more. Such a group of activities is exemplified in the TERA proposal, and includes: translating or otherwise adapting works for use in assignments and examinations, or performing or otherwise communicating works in an educational context, including by wire or wireless means (Article 5(2) b) iii) and iv).

The second problem is the limitation to educational establishments. The condition that the use should be restricted to educational institutions is a consequence of defining 'teaching' with the focus on the institutional

\footnotetext{
78 Barta, Markiewicz (2016): 256; Stanisławska-Kloc (2015): 416; Ślęzak (2017): point II.

79 On on the impact of Internet on education, see Selwyn (2014): 18-20.

80 Dussolier (2013): 361; Barta, Markiewicz (2016): 256; Stanisławska-Kloc (2015): 416.

81 Seng (2016): 49.

82 Seng (2016): 29.
} 
framework, as under the Berne Convention. ${ }^{83}$ The concept of 'illustration for teaching' supports this reading: a teacher may use works for illustrations in the class, during a museum or theatre class, or in the materials prepared for e-learning. Article 5 of the DSM Directive refers to the premises of educational establishments or other venues, or a secure electronic environment used by this institution. These conditions aim at creating clear limits for educational use. Another concept that has just been introduced to the provisions on educational uses is that of a 'responsibility of educational establishment' (Article 5(1) DSM Directive). In the TERA proposal on the other hand, the focus is on 'educational and research activities' and not on 'educational institutions'. ${ }^{84}$ When it comes to 'public' activities, such as performance or communication, the limits are imposed by 'educational context'. It is important to note that according to the TERA proposal, any natural or legal entity engaged in educational (or research) activity is the beneficiary of the limitation or exception..$^{85}$ 'Educational context' in TERA is derived from the phrase: 'the context of educational activities', ${ }^{86}$ educational activities are exemplified and placed in the broader framework of the right to receive education. The conditions of use are imposed in Article 5(2): the use should be justified by the purpose and compatible with fair practice. This approach is definitely more favourable to broad educational uses.

The list of educational activities that Member States must permit in their legislation is a valuable guideline. If the current copyright rules are a starting point for enumerating permitted educational activities, than the picture seems incomplete in terms of reflecting educational needs, as for example the eight categories of limitations and exceptions to the benefit to educational institutions. ${ }^{87}$ If what is and may be done by teachers and students/ pupils is a starting point, a much broader range of educational activities appears, for example as the context for the EU law analysis. ${ }^{88}$ Other studies use hypothetical scenarios of new possibilities for educational environments, such as a virtual campus, ${ }^{89}$ or everyday cases like sharing an article with students via the school's closed network. ${ }^{90}$ With this approach it becomes clear that not all potential educational activities fall within the scope of limitations and exceptions in the European Union. The question might be: should they?

In my opinion, it should be an essential feature of quality education that educational activities cannot be listed in an enumerative way. The concept of 'illustration for teaching' can easily be used as narrowing what can legitimately be done in the educational institutions and limit the use of different

\footnotetext{
83 See also Dussolier (2013: 360) on the understanding of 'education' and 'teaching'.

84 Band, Flynn (2018): 4.

${ }_{85}$ Article 2(1) TERA. Band, Flynn (2018): 4.

86 Band, Flynn (2018): 7.

87 Seng (2016): 15.

88 Dussolier (2013): 355.

89 European Commission (2016): 132.

90 Nobre (2017): 30.
} 
educational methods, like the project method. ${ }^{91}$ or presenting the results of students' work outside class. Furthermore, it does not reflect the idea that a pupil/ student should be active in education, and that education is a process (for example one learns how to quote) and builds upon one's experience.

Building upon the generally described 'use for educational purpose', and applying the interpretation of 'illustration for teaching' as equivalent to 'educational/ teaching purpose' purpose' would thus be the right way forward. Some may however be concerned that there are no limits to educational use, as Mark Twain observed, 'a person that started in to carry a cat home by the tail was gitting knowledge that was always going to be useful to him. ${ }^{92}$ However, numerous studies and examples demonstrate however that we are able to identify educational uses. ${ }^{93}$ The example of the Cordóba case showed how the educational practice of a pupil, combined with public praise and showing her work, escaped the EU and national framework. There was clearly, as AG Sánchez-Bordona pointed out, an educational use, ${ }^{94}$ that might have failed to satisfy the conditions for quotations. A clear link to school activity led instead to finding that teachers were liable as in Störer under German law. ${ }^{95}$

In the current EU law, the scope of digital uses in the secured online environment is too narrow from the perspective of the educational exchange of ideas. Instead, the concept of 'educational responsibility' could be developed. The policy objectives common for copyright and education should furthermore focus on the recognition of sources and methods of quoting. As the recent CJEU judgements demonstrate, there is a potential for a more liberal approach to quotations, justified by the freedom of expression. ${ }^{96}$ Copyright policy objectives in education should be to deter from piracy, to build the recognition of an 'author' and an 'investment'. TERA, for example, contains no provision on attribution nor the indication of a source. The recognition of a source, a critical approach to texts, images and videos, in terms of their value, origin and informative content, is a priority for any 'knowledgeable' and media literate society in the age of disinformation.

Katarzyna Klafkowska-Waśniowska

Adam Mickiewicz University, Poznań

kwasn@amu.edu.pl

https://orcid.org/0000-0003-4164-979X

91 On the project method as one of the methods focused on active participation and experience, see, e.g. Maciak (2012): 227-230; this method is included in the compulsory general education programme (podstawa programowa dla ksztalcenia ogólnego), e.g. at <https://podstawaprogramowa.pl/Szkola-podstawowa-IV-VIII>.

92 Twain (1874) Tom Sawyer Abroad. The quote is commonly repeated as: 'a man who carries a cat by the tail learns something he can learn in no other way'.

${ }_{93}$ The analysis of the educational activities continue, for example, with a typology prepared for SCCR WIPO session in 2019, by Seng: Educational Activities Copyright Exceptions: Typology Analysis, Geneva 2019, SCCR/38/8.

94 Opinion of Advocate General Campos Sánchez-Bordona in case C-167/15: para. 123.

95 Ling (2019).

96 Judgements in Spiegel-Online C-516/17 and Pelham C-476/17. 
Band J., Flynn, S. (2018). Section by section analysis. A Treaty on copyright exceptions and limitations for educational and research activities (TERA) November 2018, <http://infojustice. org/wp-content/uploads/2018/11/TERA-Section-by-Section-Analysis.pdf>.

Barta, J., Markiewicz, R. (2016). Prawo autorskie. Warsaw.

Błeszyński, J. (1985). Prawo Autorskie. Warsaw.

Błońska, B. (2019). Komentarz do art. 27, [in:] W. Machała, R.M. Sarbiński (eds.), Prawo autorskie i prawa pokrewne. Komentarz. [Online]. Warsaw.

Bukowski, M., Marcinkowska, J. (1997). Dozwolony użytek szkolny. Zeszyty Naukowe Uniwersytetu Jagiellońskiego 2: 91-96.

Dreier, T. (2006). Berne Convention for the Protection of Literary and Artistic Works, [in:] T. Dreier, P.B. Hugenholtz (eds.), Concise European Copyright Law. Wolters Kluwer: 7-86.

Dussolier, S. (2013). Limitations and exceptions to copyright and related rights for libraries, research and teaching uses, [in:] J.P. Triaille (ed.), Study on the application of Directive 2001/29/EC on Copyright and Related Rights in the Information Society: 243-400.

European Commission (2016). Assessment of the impact of the European copyright framework on digitally supported education and training practices. Final report. Research team: R. Domčius, R. Xalabarder, P. Junas, D. Pocius, K. Šaduikis, T. Šakünas. <https://publications.europa.eu/ en/publication-detail/-/publication/6d1d28ca-e191-4118-8e65-83130a49f535>.

Gienas, K. (2016). Komentarz do art. 27, [in:] E. Ferenc-Szydełko (ed.), Ustawa o prawie autorskim i prawach pokrewnych. Komentarz. [Online]. Warsaw.

Groeger, G. (1937). Prawo autorskie: ustawa o prawie autorskiem z r. 1926 w brzmieniu jednolitego tekstu z 1935 r. z objaśnieniami i dodaniem Konwencji berneńskiej. Księgarnia Prawnicza

Grzybowski, S., Serda, J., Kopff, A. (1973). Zagadnienia prawa autorskiego. Warsaw.

Levitas, A., Herczyński, J. (). Decentralizacja w Polsce 1989-2000 - tworzenie systemu. Ośrodek Rozwoju Edukacji. <www.ore.edu.pl>.

Ling, P. (2019). Copyright Infringement Confirmed, but No Damages for "Cordoba" Photographer. <http://ipkitten.blogspot.com/2019/07/copyright-infringement-confirmed-but-no.html>.

Maciak, G. (2012). Możliwości wykorzystania metody projektu do pracy z dziećmi w przedszkolu. Społeczeństwo i Edukacja. Międzynarodowe Studia Humanistyczne 1: 219-237.

Marcinkowska, J. (2004). Dozwolony użytek w prawie autorskim. Cracow.

Masouyé, C. (1978). Guide to the Berne Convention. Geneva 1,

Nobre, T. (2017). Copyright and education in Europe. 15 everyday cases in 15 countries, Final Report. <https://www.communia-association.org/wp-content/uploads/2017/05/15casesin15countries_FinalReport.pdf>.

Osmańska, M. (2014). Wykorzystywanie utworów w dydaktyce w świetle ochrony autorskoprawnej. Dozwolony użytek i otwarte zasoby edukacyjne. Themis Polska Nova 2(7): 190-223.

Pacek, G. (2019). Komentarz do art. 27, [in:] A. Michalak (ed.), Ustawa o prawie autorskim i prawach pokrewnych. Komentarz. [Online]. Warsaw.

Preussner-Zamorska, J., Marcinkowska, J., Laskowska, E. (2017). Dozwolony użytek, [in:] System prawa prywatnego. Prawo autorskie. Warsaw: 565-694.

Ritterman, S. (1937). Komentarz do ustawy o prawie autorskim z przedmową Stefana Sieczkowskiego wiceministra sprawiedliwości. Cracow.

Ricketson, S. (2003). Study on the limitations and exceptions. <https://www.wipo.int/edocs/mdocs/ copyright/en/sccr_9/sccr_9_7.pdf>.

Selwyn, N. (2014). The Internet and education. OpenMind. <www.bbvaopenmind.com>.

Seng, D. (2016). Study on copyright limitations and exceptions for educational activities. $<$ https:// www.wipo.int/edocs/mdocs/copyright/en/sccr_33/sccr_33_6.pdf>.

Stanisławska-Kloc, S. (2015). Komentarz do art. 27, [in:] D. Flisak (ed.), Prawa autorskie i prawa pokrewne. Komentarz Lex. Warsaw.

Ślęzak, P. (ed.) (2017). Ustawa o prawie autorskim i prawach pokrewnych. Komentarz. Komentarz do art. 27. Legalis. Warsaw.

Torres, M., Xalabarder, R. (2019). Report on practices and challenges in relation to online distance education and research activities, WIPO. < https://www.wipo.int/edocs/mdocs/copyright/en/sccr_39/sccr_39_6.pdf>.

Traple, E. (2011). Komentarz do art. 27, [in:] J. Barta, R. Markiewicz (eds.), Prawo autorskie i prawa pokrewne. Komentarz. Warsaw. 
Lewinski, S. von (2010). Rental and lending rights Directive, [in:] M.M. Walter, S. von Lewinski, European Copyright Law: A Commentary. Oxford.

Xalabarder, R. (2009). WIPO Study on Copyright Limitations and Exceptions for Educational Activities in North America, Europe, Caucasus, Central Asia and Israel.

\section{HISTORY WILL TEACH US NOTHING? \\ THE EVOLUTION OF THE COPYRIGHT FRAMEWORK FOR EDUCATIONAL USES}

\section{Sum mary}

This article contributes to joins the discussion on the copyright framework for educational uses, focusing on the analysis of Article 27 of the Polish Copyright Act, Article 5 of the Directive on copyright and related rights in the Digital Single Market, and Article 10 of the Berne Convention. Polish copyright law, the Berne Convention and EU Directives are analysed from the historical perspective to answer the question of whether the legal framework for limitations and exceptions for educational uses has changed to respond adequately to the needs of modern education. The concept of 'illustration for teaching' is critically analysed, leading to the conclusion that it reflects narrow approach which fails to address pupils/ students' activities sufficiently. The objective of the article is to emphasize that modern education needs a flexible approach to educational activities with the use of works. It is emphasized that the objectives of education and copyright are converging, particularly in the area of the conscious use and adequate description of the source of information.

Keywords: copyright; limitations and exceptions; digital teaching activities; education; Directive on copyright and related rights in the Digital Single Market 
